\title{
DESIGNING A MODEL TO INVESTIGATE THE ROLE OF THE FACTORS FORMUIATION PUBLIC POLICIES IN THE IMPLEMENTATION OF THE ADMINISTRATIVE SYSTEM HEALTH POLICY
}

\author{
Professor Dr. Sorush Niknamian \\ Board Member of Weston A Price Foundation, Washington Dc, USA \\ E-mail: so.niknamian@gmail.com
}

\begin{abstract}
The purpose of this study is to design a model to investigate the role of the Individuals making public policies in the implementation of the administrative system health policy. Two questionnaire has been used in the current study: One whose main aim was to investigate the actors making public policy with 51 questions and Cronbach Alpha 0.93, and the other one in the administrative system health policy with 74 questions and Cronbach Alpha 0.95. To be assured with regard to the validity of the questionnaires content and construct validities were estimated. The statistical population of the current study were 86643 employers of the executive organizations of the Khuzestan province, Iran. The final sample of the study was 382 individuals based on Cochran. Data analysis was done by using SPSS 22 and Amos 22. The results of the current study revealed that the factors making the public policy included 13 factors in which the most average was for mass media (7.64) and the least was the powerful elites with the mean of (5.64). The health administrative policies included 14 policies, all of them were at significant point except the policies of eleventh to thirteenth of the fifth book "Islamic Panel Code", the law of banning more than on job, and the principles of prevention and fighting against bribe. The results also showed that there was a statistically significant relationship between the factors making public policy and those of administrative health policy.
\end{abstract}

Keywords: public policy formulation, the factors making public policy, implementation of public policy, administrative health

\section{Introduction}

When a society and the government are established in a national scope, some problems and issues are inevitable which although they are in relation to the individuals, the essence of them is different from the individualistic problems. To remove these problems, some solutions need to be implemented; most of the time selected by government [1].

One of the methods to remove the problems of the society is to compile public policies. Formulation policies is a set of approaches obtained by identifying a vast scope of the methods about a problem and then identifying and designing a complex political tools which show the approach [2].

One of the problems which can be seen in the society is administrative corruption. If the aim of administrative system is to achieve positive and complete health, the related factors should be paid attention. In different research studies different factors are named to prevent administrative corruption. The factors such as organization structure, organizational culture, human resources improvement, clarity, performance evaluation, technology use, financial organization, equipping resources, etc. which have an internal essence. Moreover, other factors such as monitoring admiration, the environment and the culture are regarded as the influential external factors to the administrative health which have important role in the governmental organizations [3].

The healthy administrative system will lead to the development of the government in different aspects by reducing the costs while the corrupted administrative system will consume the social finance is like a 
marsh which plunge the resources, or by increasing the costs disrupt the development and limit the prediction of financial status [4].

The Iranian administrative, although has a modern appearance, cannot function as a modern institution. This incapability is a social problem, meaning that the managers, employers, and clients do not understand the pathologic status. Some evidence such as failure to achieve administrative goals, low efficiency, unsatisfied clients, insufficient financial health of the organization, low job satisfaction, slow official processes, organization untidiness, etc. show that there are traces of administrative corruptions in the Iranian administrations [5].

Because of this, the Islamic Republic of Iran do its best to confront the administrative corruptions by legislating various laws. Given that, in the current study, the researchers explored the factors related to formulation public policy and ranked them; moreover, the administrative system health policies were evaluated. That said, the researchers were to investigate the relationship between the factors making public policy and the implementation of administrative system health policies and the quest of what the status of implementation of such policies.

\section{Literature Review}

Making public policy is a complex, to some extent sustainable, and purposeful measures done by the government to solve the public problems and issues of the society [6]. In the studies conducted on policy making, many definitions have been introduced for public policy making. Anderson has provided a comprehensive definition. According to Anderson, public policy making is a set of purposeful and sustainable measure done by a factor or many factors in confronting an issue or problem. The current definition considers what have been done, not what is going to be done. Consequently, the policy is a decision which is different from other elements and it will be clear during a period of time [6].

Althaus et al. (2007) introduced a-eight-step approach for policy making in Australia. The approach includes identifying the issue, analyzing of the policy, developing policy instruments, policy consulting, coordination, decision, implementation, and finally, evaluation. For Lasol [8; 9] public policy has got seven steps: Information or intelligence, recommendation, version, pray, practical program, evaluation and ending.

\section{Formulation public policy}

Formulation policy is a step before decision making regarding policy which includes identifying and making a set of political alternatives for confronting the problems and taking account for the final decision regarding them [10]. When the time for decision making reach, the leading factors are those which are qualified. In another word, the decision making step is referring to those individuals who are the summits of the government. Others, who are in the lower levels either national or international, will be put aside. Just the summits and judges have a voice in this cycle and can vote [11].

However, this does not mean that other individuals in the other levels of the government do not have any role in decision making. These individuals can do different activities to encourage others to accept or reject the policies [11].

Formulation policies and strategic approaches are time consuming, complex, and time consuming, however, successful implementing them are more complex. Indeed, if the policy is not implemented correctly, all the hopes to see the expected effects will be removed [12].

Mankins and Steele conducted a study to bridge the gap in the designing and implementing the policies. These include, making the policy simple, being realistic with regard to policies, negotiating the main issue, using the policy seriously, developing communication, using the resources correctly, clarifying the policies and strategies, observing the implementation and making new capacities of implementation [13]. Implementation step includes activities to improve knowledge and skill, and facilitate the process of change [14]. It is for long time that the implementation step of the policy making is considered as a separate step in the process of policy making. It is the representation of a political idea or expected one to remove the societal problems. 
Palembo and Calista believe that some conditions are necessary, based on wisdom, to implement the policies successfully. These conditions include stating the issue correctly, providing approaches for administrative, existing management skills for sustaining the priority even in the financial and societal change conditions [15] Other researchers provided different elements which are important in the implementing a policy successfully $[16 ; 17 ; 18 ; 19 ; 20]$. Not paying attention to such factors which are important to successful implementation of the policies will lead to challenges. Researchers have introduced other challenges such as globalization and its requirements [21;22], the human essence, social events, and social principles [23], the beilifes of the main individuals in implementing the policy, the type of cooperation among individual implementing the policy [18], communication elements, and the factors related to the ability of the conductors [23].

\section{The administrative system health policy}

The administrative system health policy is regarded as a situation in which all of the elements of the organization have the capacity to provide the necessities to reach the goals of the organization; moreover, to identify the problems and deviation and provide solution for them [24].

The corruption is now varying in types in different cultures, systems and economy. First, it was regarded as a crime, and social deviation. Second, corruption is a combination of different factors such as individual profits, main parameters, structural conditions, and ethical considerations. Third, corruption involves different peoples including individuals, groups, organizations, professional, political, social, economic backgrounds, take national, local, and international measures. Moreover, corruption may be evident or hidden, or systematic [2].

After paying attention to applied corruption, it was regarded as the facilitators and fresh air for those who work and live in the Bureaucratic contexts who are put aside. Besides, corruption can be regarded as an element of competition, if not, it will be restricted [25]. In order to cope with the administrative corruption and to assure administrative health, different policies have been made which are shown below:

Table 1- The health of administrative system Policies

\begin{tabular}{|l|l|}
\hline NO. & Administrative Health Policies \\
\hline 1 & Islamic Republic of Iran outlook \\
\hline 2 & Administrative system health program \\
\hline 3 & $\begin{array}{l}\text { The eight-article decree by the Supreme Leader in May 2001 (known as the Charter of Fight } \\
\text { against Economic Corruptions) }\end{array}$ \\
\hline 4 & Sections 14 and 16 of the public policies of the fifth development plan \\
\hline 5 & Articles 90, 91 and 92 of the National Services Management Act \\
\hline 6 & $\begin{array}{l}\text { Administrative system health promotion and fight against corruption program adopted by the } \\
\text { Cabinet of Ministers on 2004/03/02 }\end{array}$ \\
\hline 7 & $\begin{array}{l}\text { Administrative System Health Promotion and Fight against Corruption Act adopted by Iranian } \\
\text { Parliament }\end{array}$ \\
\hline 8 & $\begin{array}{l}\text { The law on the intensification of the punishment for perpetrators of bribery, embezzlement and } \\
\text { fraud, approved on 1988/06/12 }\end{array}$ \\
\hline 9 & Panel code for disruptors of economic system of the country, approved on 1990/19/12 \\
\hline 10 & $\begin{array}{l}\text { The law of accession of the Islamic Republic of Iran to the United Nations Convention against } \\
\text { Corruption, adopted on 2008/11/10 }\end{array}$ \\
\hline 11 & The law on prohibition of receiving commissions in foreign transactions, approved on 1993/17/07 \\
\hline 12 & $\begin{array}{l}\text { The law on prohibition of having more than one governmental occupations, approved on } \\
1995 / 01 / 01\end{array}$ \\
\hline 13 & Chapters 11-13 of the fifth Book of Iran Islamic Penal Code \\
\hline 14 & $\begin{array}{l}\text { Regulations on preventing and combating bribery in executive agencies, approved by the Cabinet } \\
\text { of Ministers on 2004/21/11. }\end{array}$ \\
\hline
\end{tabular}


Based what have been stated above, the following conceptual model of the current research is as bellow:

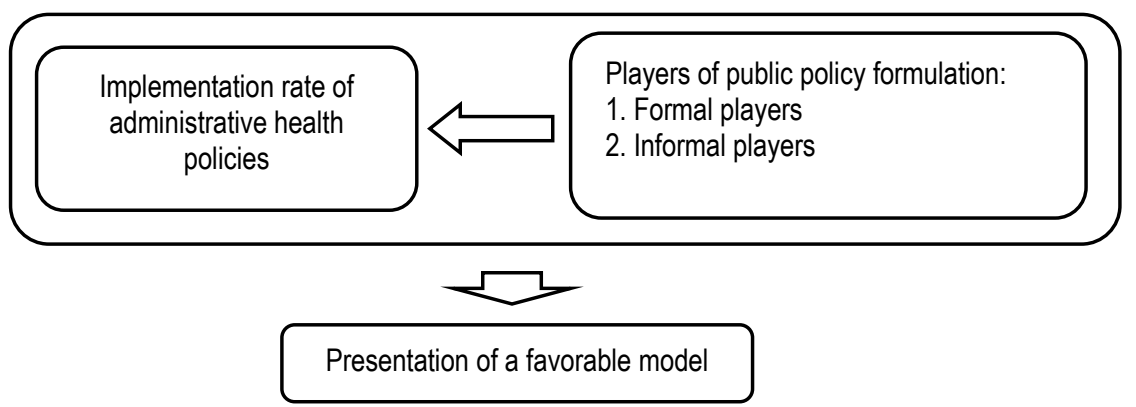

Figure 1- Conceptual model of the research

\section{Research Questions}

1. Who are the individuals making public policies?

2. How are players of public policy formulation ranked in terms of importance?

3. What are the public policies related to the health of the administrative system?

4. What is the status of implementing public policies related to the health of the administrative system?

5. What is the relationship between those who make public policy and the extent to which the policy is implemented?

6. What is the validity of the extracted model?

\section{Methodology}

The current study is a developmental-applied one regarding its purpose and a descriptive study. Moreover, this study can be regarded as a case study if its statistical population be at focus. Furthermore, the data collection procedure and the conceptual model of the research made it as a survey and exploratory study, respectively. Two questionnaires have been used in the current study: One whose main aim was to investigate the actors making public policy with 51 questions, and the other one in the administrative system health policy with 74 questions. The statistical population of the current study were 86643 employers of the executive organizations of the Khuzestan province (of total 23 cities of this province), Iran. The final sample of the study was 382 individuals based on Cochran. To answer the research questions Pearson coefficient, Freedman test, and independent sample t-test were used.

\section{Findings}

\section{Who are the individuals making public policies?}

Based on the conceptual model of the study the individuals who involve in policy making are: Those in legislature, executive, and judiciary, the Supreme National Security Council, the Expediency Council. Moreover, the informal individuals include the media, influential groups, the people, powerful elites, religious and traditional parties, and political parties.

Table 2- the fitness indexes of confirmatory factor analysis of the first questionnaire: individuals involve in the policy making

\begin{tabular}{|c|c|c|c|c|c|c|c|c|c|}
\hline Indexes & $\mathbf{x}^{\mathbf{2}}$ & $\mathbf{d f}$ & $\mathrm{df} / \mathrm{x}^{\mathbf{2}}$ & $\mathbf{G F I}$ & AGFI & RMSEA & NFI & IFI & CFI \\
\hline The estimated amount & 4.2789 & 1211 & 2.30 & 0.88 & 0.85 & 0.80 & 0.81 & 0.90 & 0.91 \\
\hline
\end{tabular}

In the current study the df is 1211 for 382 participants which is more than 1.96. Consequently, it caused the under estimation of GFI and AGFI. Moreover, the amount of RMSEA is 0.80 which shows the fitness 
is appropriate. All in all, the results indicated an appropriate fitness which indicate that the model can be used for determining the individuals making policy.

\section{What is the role of each of them and what is the importance of their rank?}

Table 3- The status of variables of individuals involve in policy making

\begin{tabular}{|c|c|c|c|c|}
\hline Variables & \multicolumn{4}{|c|}{ Expected mean= 3 } \\
\hline & mean & T & df & p-value \\
\hline Legislature & 3.1944 & 6.741 & 381 & 0.000 \\
\hline Executive power & 3.2051 & 9.232 & 381 & 0.000 \\
\hline Judiciary & 3.2062 & 8.218 & 381 & 0.000 \\
\hline Supreme National Security Council & 3.0825 & 3.434 & 381 & 0.000 \\
\hline Expediency Council & 3.1505 & 6.281 & 381 & 0.000 \\
\hline Mass media & 3.2134 & 8.545 & 381 & 0.000 \\
\hline Interest groups & 3.1497 & 5.332 & 381 & 0.000 \\
\hline The general public & 3.1579 & 5.640 & 381 & 0.000 \\
\hline Political research centers & 3.0253 & 0.890 & 381 & 0.374 \\
\hline Powerful elites & 3.0118 & 0.392 & 381 & 0.696 \\
\hline Pressure groups & 3.2356 & 8.385 & 381 & 0.000 \\
\hline Religious and traditional references & 3.1728 & 5.713 & 381 & 0.000 \\
\hline Political parties & 3.1518 & 4.929 & 381 & 0.000 \\
\hline
\end{tabular}

* Significant level: 0.05 .

Based on the obtained results on Table 3, since the obtained p-value is less than 0.01 , it can be concluded with more than $99 \%$ that the obtained mean score for the individuals making policy and the fix mean are statistically different $(\mathrm{t}=13.45, \mathrm{p}=0.000, \mathrm{df}=391)$. Based on Bazargan table, the obtained mean score is on a more satisfaction level.

\section{What are the public policies related to the health of the administrative system?}

To describe the administrative health policies, it should be stated that these policies are Administrative Health Policies, Principles document of future perspectives of the Islamic Republic of Iran, Administrative system health program, eight commandments of the Supreme Leader, article 14 and 16 of the public policy of the fifth development plan, Materials 90, 91 and 92 of the State Service Management Act, Government, Health Promotion Program and Anti-Corruption Council approved by the Ministers on $10 / 3 / 2003$, The law on the promotion of the health of the administrative system and the cope to parliamentary corruption, The law of aggravating the punishment of those who get bribery was approved on 1988, The Penal Code of Disrupters in the Economic System of country, dated 12/12/1990, The Act of Accession of the Islamic Republic of Iran to the United Nations Convention against Corruption, adopted on 10/10/2008, The law prohibiting the purchase of foreign exchange transactions approved in 1994, The law prohibiting the possession of more than one job related to government approved on 1/1/1994, Eleventh to Thirteenth of The Islamic Penal Code, The Code of Prevention and Coping Bribery in, Executive Agencies, approved by the Ministers on 10/12/2004.

Table 4- The fitness indexes of confirmatory factor analysis of the second questionnaire: administrative system health

\begin{tabular}{|c|c|c|c|c|c|c|c|c|c|}
\hline Indexes & $\mathrm{x}^{2}$ & Df & $\mathrm{df} / \mathrm{x}^{2}$ & GFI & AGFI & RMSEA & NFI & IFI & CFI \\
\hline $\begin{array}{c}\text { The estimated } \\
\text { amount }\end{array}$ & 6856.5 & 2611 & 2.62 & 0.89 & 0.85 & 0.08 & 0.90 & 0.89 & 0.89 \\
\hline
\end{tabular}


In the current study the df is 2611 for 382 participants which is more than 1.96 . Consequently, it caused the under estimation of GFI and AGFI. Moreover, the amount of RMSEA is 0.08 which shows the fitness is appropriate. All in all, the results indicated an appropriate fitness which indicate that the model can be used for determining the administrative system health.

\section{What is the status of implementing public policies related to the health of the administrative system?}

Table 5- The status the components of related the administrative system health

\begin{tabular}{|l|c|c|c|c|}
\hline \multicolumn{1}{|c|}{ Variables } & \multicolumn{3}{c|}{ Expected mean = 3 } \\
\hline \multicolumn{1}{|c|}{} & mean & $\mathrm{T}$ & $\mathrm{df}$ & $\mathrm{p}$-value \\
\hline Islamic Republic of Iran outlook & 3.0785 & 2.179 & 381 & 0.030 \\
\hline Administrative system health program & 3.2312 & 8.501 & 381 & 0.000 \\
\hline $\begin{array}{l}\text { The eight-article decree by the Supreme Leader in May 2001 (known } \\
\text { as the Charter of Fight against Economic Corruptions) }\end{array}$ & 3.2609 & 8.082 & 381 & 0.000 \\
\hline $\begin{array}{l}\text { Sections 14 and 16 of the public policies of the fifth development } \\
\text { plan }\end{array}$ & 3.1990 & 7.611 & 381 & 0.000 \\
\hline Articles 90, 91 and 92 of the National Services Management Act & 3.1710 & 6.353 & 381 & 0.000 \\
\hline $\begin{array}{l}\text { Administrative system health promotion and fight against corruption } \\
\text { program, adopted by the Cabinet of Ministers on 2004/03/02 }\end{array}$ & 3.2248 & 10.141 & 381 & 0.000 \\
\hline $\begin{array}{l}\text { Administrative system health promotion and fight against corruption } \\
\text { law, adopted by the parliament }\end{array}$ & 3.1207 & 5.942 & 381 & 0.000 \\
\hline $\begin{array}{l}\text { Law on intensification of punishment of perpetrators of bribery, } \\
\text { embezzlement and fraud, approved on 1988/06/12 }\end{array}$ & 3.1710 & 5.779 & 381 & 0.000 \\
\hline $\begin{array}{l}\text { Penal code of disruptors of economic system of the country, } \\
\text { approved on 1990/19/12 }\end{array}$ & 3.1586 & 5.980 & 381 & 0.000 \\
\hline $\begin{array}{l}\text { The law of accession of the Islamic Republic of Iran to the United } \\
\text { Nations Convention against Corruption, adopted on 2008/11/10 }\end{array}$ & 3.1470 & 6.281 & 381 & 0.000 \\
\hline $\begin{array}{l}\text { The law on prohibition of receiving commission in foreign } \\
\text { transactions, approved on 1993/17/07 }\end{array}$ & 3.0611 & 1.806 & 381 & 0.072 \\
\hline $\begin{array}{l}\text { The law on prohibition of having more than one governmental } \\
\text { occupations, approved on 1995/01/01 }\end{array}$ & 2.8812 & -4.604 & 381 & 0.000 \\
\hline Chapters 11-13 of fifth book of Islamic Penal Code of Iran & 3.1518 & 4.945 & 381 & 0.000 \\
\hline $\begin{array}{l}\text { Regulations on preventing and combating bribery in executive } \\
\text { agencies, approved by the Cabinet of Ministers on 2004/21/11 }\end{array}$ & 2.8567 & -6.537 & 381 & 0.000 \\
\hline
\end{tabular}

Based on the obtained results on Table 5, since the obtained p-value is less than 0.01 for 14 components, it can be concluded with more than $99 \%$ that the obtained mean score for administrative system health and the fix mean are statistically different.

5. What is the relationship between those who make public policy and the extent to which the policy is implemented?

Table 6- The relationship between individuals making public policy and the extent of implementation of administrative system health

\begin{tabular}{|c|c|c|}
\hline Variable & $\begin{array}{c}\text { The extent to which health policy } \\
\text { implemented }\end{array}$ & $\begin{array}{c}\text { Individual making public } \\
\text { policy }\end{array}$ \\
\hline Individual making public policy & 1 & 1 \\
\hline $\begin{array}{c}\text { The extent to which health policy } \\
\text { implemented }\end{array}$ & $0.939^{* * *}$ & \\
\hline
\end{tabular}


The results of Table 6 indicated that there is a statistically significant relationship between individuals making public policy and the extent of implementation of administrative system health policy, assured more than $99 \%(\mathrm{r}=0.93)$.

\section{What is the validity of the extracted model?}

Table 7- The fit indexes for the corrected model

\begin{tabular}{|c|c|c|c|c|c|c|c|c|c|c|}
\hline Indexes & $\mathbf{x}^{2}$ & $\mathbf{d f}$ & $\mathbf{d f} / \mathbf{x}^{2}$ & $\boldsymbol{G F I}$ & $\boldsymbol{A G F I}$ & $\boldsymbol{N F I}$ & $\boldsymbol{I F I}$ & $\mathbf{T L I}$ & $\boldsymbol{C F I}$ & $\boldsymbol{E M S E A}$ \\
\hline $\begin{array}{c}\text { Calculated } \\
\text { value }\end{array}$ & 1.834 & 324 & 2.57 & 0.83 & 0.87 & 0.93 & 0.91 & 0.89 & 0.87 & 0.06 \\
\hline $\begin{array}{c}\text { Acceptable } \\
\text { level }\end{array}$ & & & $<3$ & $>0.90$ & $>0.90$ & $>0.90$ & $>0.90$ & $>0.90$ & $>0.90$ & $<0.1$ \\
\hline Result & Fit & Fit & Fit & acceptable & acceptable & Fit & Fit & Fit & acceptable & Fit \\
\hline
\end{tabular}

Table 7 shows the values of different indices used to evaluate goodness-of-fit. According to the obtained results, the model was evaluated as acceptable.

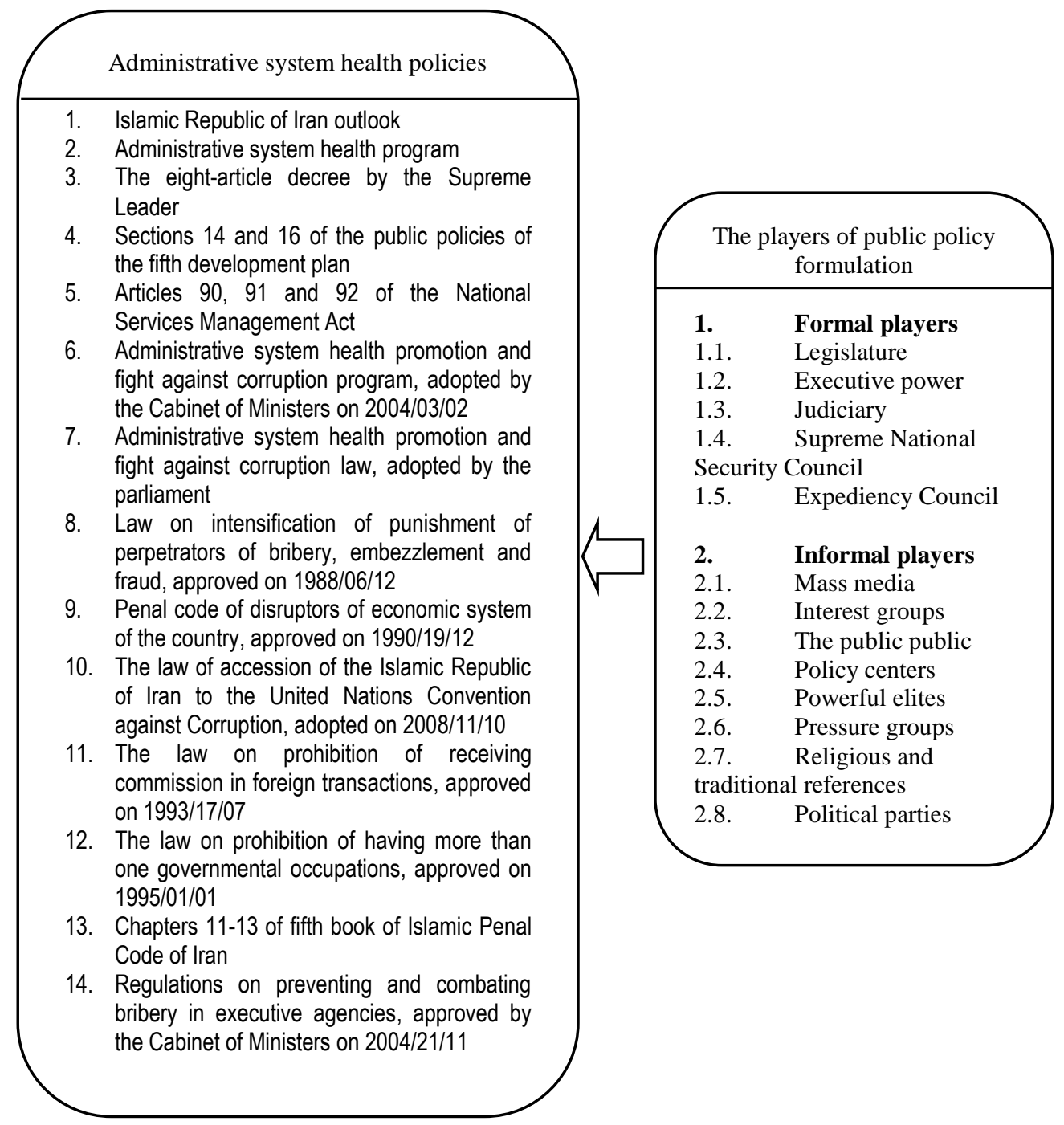

Figure 2- Final research model 


\section{Discussion and Conclusion}

1. Based on the results of the first question the individuals making public policies can be divided into formal and informal group. The formal groups include those in legislature, executive, and judiciary, the Supreme National Security Council, the Expediency Council. Moreover, the informal group include the media, influential groups, the people, powerful elites, religious and traditional parties, and political parties. That said, the results of ths study is in line with that of Asli Pour et al. (2014), Bagheri et al. (2013). Hejazifar (2012), Sinaii and Zamani (2010), Ghafori and Kamali (2010), Alvani and Sarafi zadeh (2001) and Roman (2015).

2. According to the results of the second research question, the legislature branch was $(\mathrm{M}=3.19)$ which based on Abbas Bazargan table it was with more satisfaction level. In the executive branch, with respect to the amount $(M=3.20)$, the obtained level is more than satisfactory. In the judiciary branch, with respect to the amount $(M=3.20)$, the obtained level is more than satisfactory. In the Supreme National Security Council, with respect to the amount $(\mathrm{M}=3.08)$, the obtained level is more than satisfactory. In the Expediency Council, with respect to the amount $(\mathrm{M}=3.15)$, the obtained level is more than satisfactory. In the mass media, with respect to the amount $(\mathrm{M}=3.21)$, the obtained level is more than satisfactory. In the influential groups, with respect to the amount $(\mathrm{M}=3.15)$, the obtained level is more than satisfactory. In the people, with respect to the amount $(\mathrm{M}=3.15)$, the obtained level is more than satisfactory. In political research centers, with respect to the amount $(\mathrm{M}=3.28)$, the obtained level is more than satisfactory. In the elites, with respect to the amount $(\mathrm{M}=3.01)$, the obtained level is more than satisfactory. In the opposing groups, with respect to the amount $(\mathrm{M}=3.23)$, the obtained level is more than satisfactory. In the religious and traditional parties, with respect to the amount $(\mathrm{M}=3.17)$, the obtained level is more than satisfactory. The results are in agreement with that of Zhang (2014), Birkland (2010) Gerstone (2004).

3 . With respect to the third research question, it should be noted that there were 14 components for the administrative system health policy. The results are in agreement with that of Abbasi and Jamalpur (2011), Sam Aram and Amin Aghaei (2010), Rabiei and Bigdeli (2010), Jafarlou et al (2009), Gholipour (2005), Taghavi Rafsanjani (2002), Shakrallahi (2000), Daibi and Sylwester (2014), Saha et al. (2014), Yilmaz and Akaf (2011).

4. with regard to the forth research question, in the perspective of the Islamic Republic of Iran perspective, according to the amount $(\mathrm{M}=3.07)$, In the Administrative system health program, according to the amount $(M=3.23)$, In the eight commandments of the Supreme Leader, according to the amount $(M=3.26)$, In the article 14 and 16 of the public policy of the fifth development plan, according to the amount $(M=3.19)$, In the Materials 90, 91 and 92 of the State Service Management Act, according to the amount $(M=3.17)$, In Government Health Promotion Program and Anti-Corruption Council approved by the Ministers on $10 / 3 / 2003$, according to the amount $(M=3.22)$, In The law on the promotion of the health of the administrative system and the cope to parliamentary corruption, according to the amount $(\mathrm{M}=3.12)$, In The law of aggravating the punishment of those who get bribery was approved on 1988, according to the amount (M=3.17), In The Penal Code of Disrupters in the Economic System of country, dated 12/12/1990, according to the amount $(\mathrm{M}=3.15)$, In The Act of Accession of the Islamic Republic of Iran to the United Nations Convention against Corruption, adopted on 10/10/2008, according to the amount $(M=3.14)$, In The law prohibiting the purchase of foreign exchange transactions approved in 1994, adopted on $10 / 10 / 2008$, according to the amount $(M=3.06)$, In The law prohibiting the possession of more than one job related to government approved on 1/1/1994, according to the amount $(M=2.28)$, In Eleventh to Thirteenth of The Islamic Penal Code $(\mathrm{M}=3.18)$, in the The law prohibiting the possession of more than one job related to government approved on $1 / 1 / 1994$, according to the amount $(\mathrm{M}=2.85)$ based on Bazargan Table all were satisfactory. The results were in line with that of Kamali (2014), Amani (2011), Sheikhi (2011), Iranzadeh and Davoodi (2012), Anderson (2009), Fletcher (2005), Serra (2004), Graff and Mahlow (2003).

5. To answer the fifth research question which asks for the relationship between the role of individuals making policy and the extent to which administrative system health policy is implemented Pearson coefficient was used. The results of Table 4 indicated that there was a statistically significant relationship 
between the two variables $(\mathrm{p}=0.000<0.01 ; \mathrm{r}=0.93)$. The results are in agreement with that of Makinde (2005), Malekmohammadi (2015), Danshfard (2014), Richardson (2007), and Akreman et al. (2011).

\section{Implications}

1. In the current study, it was revealed that there are two groups of individuals who are making the public policies: the formal and informal groups. Moreover, it was revealed that the mass media has got the highest rank and the elites has got the lowest rank in making the public policies.

It is suggested that the mass media will held different programs by inviting the elites of the society to discuss and debate the public policy making procedures and provide appropriate solutions for the probable problems.

2. The results indicated a satisfactory status with regard to all of the components of public policy making. However, the components of people and political parties are in good status and political research centers and elites are satisfactory. Moreover, the results revealed that based on freedman test the highest rank was for mass media and the lowest for the elites.

Based on the statistical results and the fact that elites had got the lowest rank it can be concluded that the respondent did not want to be silent with regard to the policy making procedures, they did not want that the interest of the elites be the forerunner and determining factor in policy making.

Since the component of people had got a good status, it is suggested that NGOs will be held and interested people will be more active in public policy making. Moreover, it is suggested that establishing communities, and marching based on constitutive low will be done. Furthermore, the process of NGOs will be facilitated and a meaningful relationship will be held between people and the government.

3. the administrative system health policy includes Principles document of future perspectives of the Islamic Republic of Iran, Administrative system health program, eight commandments of the Supreme Leader, article 14 and 16 of the public policy of the fifth development plan, Materials 90, 91 and 92 of the State Service Management Act, Government, Health Promotion Program and Anti-Corruption Council approved by the Ministers on 10/3/2003, The law on the promotion of the health of the administrative system and the cope to parliamentary corruption, The law of aggravating the punishment of those who get bribery was approved on 1988, The Penal Code of Disrupters in the Economic System of country, dated 12/12/1990, The Act of Accession of the Islamic Republic of Iran to the United Nations Convention against Corruption, adopted on 10/10/2008, The law prohibiting the purchase of foreign exchange transactions approved in 1994, The law prohibiting the possession of more than one job related to government approved on 1/1/1994, Eleventh to Thirteenth of The Islamic Penal Code, The Code of Prevention and Coping Bribery in, Executive Agencies, approved by the Ministers on 10/12/2004. Based on the obtained results, all of the components except for Eleventh to Thirteenth of the Islamic Penal Code were high satisfactory. Moreover, it should be stated The law of aggravating the punishment of those who get bribery was approved on 1988 was the highest rank and article 14 and 16 of the public policy of the fifth development plan was the lowest regarding all of the components. Given that, it is suggested that reforming the administrative and judicial system, employing qualified managers and judges, decentralizing administrative areas, removing or integrating parallel administrations, and strengthening and enforcing the inspection and supervision system to prevent and cut down corruptions. To promote the Islamic penal code, it is suggested that The Islamic Penal Code will emphasize more with regard to bribery of the rulers, Rabba, fraud, the refusal of the judicial authorities to perform their legal duties, and fraud of governmental agents.

3. There is dynamicity with regard to the corruptions so that the policy makers need to consider the latest status when they are trying to make new policies and consider all aspects in this field.

\section{References}

1. Jafari, M.H. (2011). Governmental jurisprudence and public policy. Islam and management research. 1(3), 13-34.

2. Birkland, Thomas A. (2015). An Introduction to the Policy Process Theories, Concepts, and Models of Public Policy Making, Third Edition, Published 2015 by Routledge. 
3. Kamali, Y. (2014). Review the role of decentralization in the realization of administrative health. Quarterly Journal of Strategic and Military Policies, 2(5), 111-132.

4. Pope, J. (2000). Confronting corruption the Element of a National integrity system. TI sourse Book, Transparency International.

5. Ghahramani, M., \& Heydari, R. (2012). Investigating the relationship between the health of the administrative system and improving the manpower performance of governmental financial organizations in West Azarbaijan province. Quantitative Studies in Management, 4(2), 186-155.

6. Anderson, E.J. (2011). Public Policymaking: An Introduction. Seventh Edition. Boston, MA: Wadsworth Publishing.

7. Althaus. C., Bridgman, P., \& Davis, G. (2007). The Australian Policy Handbook, 4thed, Sydney: Allen \& Unwin.

8. Ezeani, E.O. (2006). Fundamentals of public administration (revised ed.). Enugu, Nigeria: Snaap Press Ltd.

9. Eminue, O.E. (2005). Public policy analysis and decision-making. Lagos, Nigeria: Concept Publications Limited.

10. Sidney, Mara S. (2007). Policy Formulation: Design and Tools. Handbook of public policy analysis: theory, politics, and methods / edited by Frank Fischer, Gerald J. Miller, and Mara S. Sidney.

11. Mounirian, A., \& Golshan, I. (2015). A study of the public policy of policy cycles and policy subtitles. Publications of the Institute of the Book of Mehrban Publishing.

12. Saqafi, A. (2008). Public Role: A Study of the Role of Rationality in the Formulation Processes, Tehran: Tarbiat Modares University.

13. Mankins, M.C., \& Steele, R. (2005). Turning Great Strategy into Great Performance. Harvard Business Review, 83 (7/8), 64-72.

14. Strehlenert, H., Richter-Sundberg, L., Nyström, M.E., \& H. Hasson (2015). Evidence-informed policy formulation and implementation: a comparative case study of two national policies for improving health and social care in Sweden. Implementation Science, 10:169

15. Palumbo D.J., \& Calista. D.J. (1990). Implementation and Policy Process: Opening up the black box; Greenwood Press Inc. USA.

16. Krutwaysho, M.O. (2003).Obstacles to the implementation of tourism policies and regulations in Phuket, Thaailand; Sheffield Hallam University; available at: http://www.esade.es/cedit2003/pdfs/krutwayshoratai.pdf.

17. Khlid, H.M. (2008).Policy Implementation Models: The case of library and documentation service in Pakistan 1998-2008; New Library World, 102(1162).

18. Yanow, D.J. (1987). Toward a policy culture approach to implementation. Public Studies Review, $7(1)$.

19. Staley, S.R. (2006). Institutional consideration for sustainable development policy implementation: A US case study. Property Management, 24(3).

20. Bobrow, D.B. (2006). Social and cultural factors: constraining and enabling; In: Moran M., Rein M. and Goodin R. E. (Ed.); The Oxford Handbook of Public Policy, Oxford University Press.

21. Hay, C. (2006). Globalization and public policy; In: Moran M., Rein M. and Goodin R. E. (Ed.); The Oxford Handbook of Public Policy, Oxford University Press.

22. Quiggin, J. (2006).Economic constraints on public policy; In: Moran M., Rein M. and Goodin R. E. (Ed.); The Oxford Handbook of Public Policy, Oxford University Press.

23. Galston, W.A. (2006).Political feasibility: Interests and power; In: Moran M., Rein M. and Goodin R. E. (Ed.); The Oxford Handbook of Public Policy, Oxford University Press.

24. Hajian, H. (2012). The law on the promotion of the health of the administrative system and the fight against corruption and threats and its opportunities for the members of the public accountant's community of auditors. Auditor, 63, 78-90.

25. De Benedetto, M. (2014). Administrative Corruption. Encyclopedia of Law and Economics. Springer Science+Business Media New York. 
26. Aslipour Poor., H. Zahedi, Sh., Sharif Zadeh, F., \& Ghorbani Zadeh, V. (2014). Explaining the Native Patterns of Environmental Policies of the Country Using the Foundation Data Theory. Strategic Management Thought, 18(1), 66-41.

27. Hejazifar, S. (21012). Policy environment. Development Strategy Journal, 30, 194-172.

28. Sinai, V., \& Zamani, S. (2011). The role of legislatures in the policy making process; towards a theoretical model. Journal of Strategy, 20(58), 93-65.

29. Ghafouri, M., \& Kamali, Y. (2010). Public opinion and public policy (theoretical). Journal of Politics, 40(2).

30. Alwani, S.M., \& Sarafizzadeh, A. (2001). Analysis of effective factors on the formation of public policies in the Islamic Republic of Iran and the provision of an optimal model. Journal of Improvement Management Studies, 29(30),142-117.

31. Roman, A. (2015). The Determinants of Public Administrators' Participation in Policy Formulation. American Review of Public Administration,1-28.

32. Zhang, X. (2014). Study on the participation of citizens in public policy formulation.

33. Gerston, L.N. (2004). Public Policy-Making: Process and Principles, 2nd ed, New York: ME Sharpe.

34. Abbasi, M., \& Jamalpur, M. (2011). The role of organizational culture in improving the health of the administrative system and the level of satisfaction of the people. Journal of Cultural Engineering, 55, 54-44.

35. Sam Aram, E., \& Amin Aghaee, M. (2010). Administrative Health and Administrative Identity in Iran. Journal of Research, 52, 54-37.

36. Rabiei, A., \& Bigdeli, M. (2010). Cultural Pathology in Promoting Administrative Health of Governmental and Nongovernmental Organizations. Journal of Religion and Communication, 18(1), 205187.

37. Jafarloo, H.R., \& Goudarzi, M., Sajjadi, S.N., Ghorbani, M.H., \& Darabi, H.A. (2009). Determining the factors influencing the incidence and spread of administrative corruption and its control methods in the Islamic Republic of Iran Physical Education Organization from the perspective of experts. Journal of Sport Management Studies (Institute of Physical Education), 4 (25).

38. Gholipour, R. (2005). Analysis of the relationship between good governance and corruption. Journal of Organizational Culture Management, 2(3).

39. Taghavi Rafsanjani, M. (2002). The role of health officials in the stability and effectiveness of political systems from the viewpoint of Amir al-Mu'minin Ali (as). Islamic Law Research Journal, 8, 78 83.

40. Shakrollahi, M. (2000). Capacity building for the health of the administrative system, promotion of the health of the administrative system, p. 7273.

41. Diaby, A., \& Sylwester, K. (2014). Bureaucratic Competition and Public Corruption: Evidence from Transition Countries, European Journal of Political Economy.

42. Saha, Sh., Rukmani, G., Neil, C and J.J. Su. (2014). Democracy and corruption: A complex relationship. Crime, Law and Social Change, 61(3), 287-308.

43. Yilmaz, A., \& Akif, M. (2011). Determinants of economic corruption: a cross-country data analysis. International Journal of Business and Social Science, 2(13).

44. Amani, N. (2011). Administrative Word: The Transitional Transition of Organizational Development. Journal of Economic City, 9.

45. Sheikh, M.H. (2011). The factors affecting the health of the administrative system and the growth of ethical values in it. Journal of Islam and management research, 1(2), 99-126.

46. Iranzadeh, Solomon and Davoodi, Full (2012). Investigating the relationship between the establishment of e-government and the health of the country's administrative system. Journal beyond management, 16(22), 74-55.

47. Anderson, J.E. (2009). Public Policy-Making: An Introduction, 7th ed, England: Wadsworth Publishing. 
48. Fletcher, P. (2002). The Government Paperwork Elimination Act. Berlin: INT'L.J Of Public Admin., pp. 162-175.

49. Serra, D. (2004). Empirical determinants of corruption: a sensitivity analysis. Global Poverty Research Group Working Paper, GPRG-WPS-012, Economic and Social Research Council, London.

50. Graeff, P., \& Mehlkop, G. (2003). The impact of economic freedom on corruption: different patterns for rich and poor countries. European Journal of Political Economy, 19(3), 605-620.

51. Makinde, T. (2005). Problems of policy implementation in developing nations: the Nigerian experience. Journal of social sciences, 11(1), 63-69.

52. Malek Mohammadi, H.R. (2015). The principles and principles of public policy. Publication Samt.

53. Knowledge of the individual, Karimollah (2013). Principles of Public Policy, Tehran: Publications Needed Knowledge.

54. Richardson, W. (2007). Public policy failure and fiasco in education: perspectives on the British examinations crises of 2000-2002 and other episodes since 1975, Oxford Review of Education Routiedge, 33(2), 143-160.

55. Akreman, J. et al., (2011). How to manage barriers to formation and implementation of policy pakages in transport, s.l.: Optic. optimal policies for Transport in Combination. 